\title{
The effect of vermiwash and vermicompost produced from leaves of Azadirachta indica and Citrus aurantifolia on the growth parameters of celery through hydroponic system
}

\author{
ABDULLAH ADIL ANSARI ${ }^{1, \boldsymbol{\nu}}$, HEERAWATTIE RAGHUBEER ${ }^{1}$, SIRPAUL JAIKISHUN ${ }^{1,2}$ \\ ${ }^{1}$ Department of Biology, Faculty of Natural Sciences, University of Guyana. Turkeyen Campus, Greater Georgetown, Guyana. Tel.: +592-222-5423, \\ Fax.: +592-222-5122, `email: abdullah.ansari@uog.edu.gy \\ ${ }^{2}$ Haxia Institute of Science and Technology, Life Sciences College, Fujian Agriculture and Forestry University, Fuzhou, China
}

Manuscript received: 3 December 2018. Revision accepted: 16 February 2019.

\begin{abstract}
Ansari AA, Raghubeer H, Jaikishun S. 2019. The effect of vermiwash and vermicompost produced from leaves of Azadirachta indica and Citrus aurantifolia on the growth parameters of celery through hydroponic system. Trop Drylands 3: 11-16. Hydroponic is a method of growing plants in water solution with additional elements including vermicompost and vermiwash generated from organic matters. This research was designed to determine the physicochemical composition of vermiwash and vermicompost produced from neem (Azadirachta indica) and lime (Citrus aurantifolia) and their influence on the growth parameters on celery (Apium graveolens) in hydroponic system. Plants were treated with six treatments-A (nutrient solution for hydroponic systems), B (vermiwash and vermicompost made from $\mathrm{T}_{1}$ ), C-control (water), $\mathrm{D}$ (vermiwash and vermicompost made from $\mathrm{T}_{2}$ ), $\mathrm{E}$ (vermiwash and vermicompost made from $\mathrm{T}_{3}$ ). All treatments were replicated six times in a complete randomized block design (CRBD). Results indicated that vermiwash and vermicompost when used in combination can be substituted for chemical hydroponic solutions used in hydroponic systems. T2 had a significant effect on celery plants where it produced plants with greater heights and stem diameter. Maximum amount of sodium was seen in plants treated with F. Plants treated with T1 had the highest number of leaves and branches. This research will further enhance the need for hydroponic agriculture as it has less detrimental effects on the environment and produces greater yield and better quality of crops.
\end{abstract}

Keywords: Hydroponic, plant nutrients, physicochemical properties, vermiwash, vermicompost

\section{INTRODUCTION}

Growing plants on soil have been developed and practiced from the beginning of human existence. However, this conventional agricultural practice can lead to difficulties in plant growth because nutrient levels in many soil types are unpredictable and may be inaccessible to some plants, also some plant diseases originate from soil. These conventional farming techniques have given the impetus to venture into more reliable alternative methods of growing crops in safer environments to improve yield quantity and quality. It also reduces the dependency on the use of pesticides on crops (Resh and Howard 2012; Treftz and Omaye 2015). Climate change together with irrigated agriculture propels soil salinization, making it more difficult to cultivate glycophytes (plants of non-saline soil). In addition, global population is rapidly increasing and may reach about 9.7 billion by 2050 . To sustain this population, the present level of agricultural production has to increase by two folds (UN 2015; Deinlein et al. 2014; Flowers and Muscolo 2015).

Hydroponics is a method of growing plants in water solution which contains the necessary nutrients for plant growth and productivity. Hydroponic agriculture results in higher yields, better quality and enhanced water use efficiency, and can be designed to support production across seasonal variations (Buchanan and Omaye 2013;
Gruda 2009; Koyama et al. 2013). In creating hydroponic system, additional elements are required to increase the nutrients including vermicompost and vermiwash. Vermicompost results from bio-oxidative processes in which decomposers disintegrate organic substrates and modify their physical and chemical properties. Earthworms (Eisenia fetida: Lumbricidae) were noted for their exemplary ability to breakdown organic matters into rich humus (Domínguez 2004; Ansari and Ismail 2012). Vermiwash is residual liquid that contains excretory and secretory products of earthworms along with micronutrients of the soil that is collected in water having passed through burrows of worm worked soil. It contains essential nutrients that are more readily available to plants and positively influence plant growth and yield (Fathima and Sekar 2014; Jaikishun et al. 2014; Prakash et al. 2016).

Earthworms are abundant in disturbed environments and active in the presence of moisture. They are detritivores and geophages (Ismail, 2005). Their contribution to the soil is evident in the mineralization of nutrients in the form of organic carbon, nitrogen, inorganic phosphorous, potassium, magnesium, and other nutrients in the excreta or worm cast from organic substrates. In making vermicompost, it is beneficial to use appropriate media (e.g. leaves) because it provides the suitable $\mathrm{pH}$ to optimize the functionality of earthworms in the soil. Two promising leaves are from lime and neem plants. 
Constituents of lime (Citrus aurantifolia: Rutaceae) have provided many health benefits to us over the years. Potentially, lime is antibacterial, antifungal, antidiabetic, and anticancerous (Daniels 2006; Balamurugan 2014; Nwankwo et al. 2015). It also contains copious phytochemicals and bioactive compounds that are significantly useful to humans. Compounds extracted from neem (Azadirachta indica: Meliaceae) have been used traditionally to cure many infectious diseases and shown to be chemo-preventive with antitumor effects in different types of cancer (Paul et al. 2011; Hao et al. 2014). Neem aids in healthier earthworms because they feed insatiably on neem, converting $7 \%$ of the feed into vermicompost daily. Earthworms grow faster and reproduce more rapidly in neem-fed vermireactors (Gajalakshmi and Abbasi 2004).

The objectives of this study are to determine the physicochemical composition of vermiwash and vermicompost produced from different substrates of lime and neem leaves, and to use such vermicompost and vermiwash to grow celery in hydroponic system. Celery (Apium graveolens: Apiaceae) has antioxidant potential and many other chemicals that are beneficial to our health (Gauri et al. 2015; Kooti and Daraei 2017).

\section{MATERIALS AND METHODS}

\section{Study site}

The units were set up at the University of Guyana, Turkeyen Campus while the hydroponics systems were arranged at Georgetown, Prashad Nagar for plants to be grown. Physicochemical analyses were conducted at GuySuCo's laboratory. Microbial analyses were done at the Faculty of Natural Sciences Laboratory, University of Guyana.

\section{Preparing the vermiwash units}

Three (3) square five gallon bottles were selected for the units. A tap was fixed on the lower side of each container in such a way to be easily drained and to facilitate collection of vermiwash. About $20 \mathrm{~cm}$ of broken pebbles were placed at the bottom of each container followed by $20 \mathrm{~cm}$ of coarse sand. Water was allowed to flow through these layers enabling the settling of the basic filter unit. After that, a $22 \mathrm{~cm}$ layer of loamy soil was added on top of the filter bed. Then, 25 earthworms were introduced into the soil of containers with $200 \mathrm{~g}$ cattle dung $+150 \mathrm{~g}$ Lime leaves $\left(\mathrm{T}_{1}\right), 200 \mathrm{~g}$ cattle dung $+150 \mathrm{~g}$ Neem leaves $\left(\mathrm{T}_{2}\right)$, and $200 \mathrm{~g}$ cattle dung $+75 \mathrm{~g}$ neem leaves $+75 \mathrm{~g}$ lime leaves $\left(\mathrm{T}_{3}\right)$ (Figure 1.A). Units were moistened (10 min) and drained every two days. Microbial and physicochemical analyses were conducted on vermiwash and vermicompost. The samples were analyzed for the following physicochemical properties: $\mathrm{pH}$, organic carbon, nitrogen, potassium, available phosphate, exchangeable calcium, exchangeable magnesium, zinc, iron, copper and manganese (Homer 2003).

\section{Preparing the hydroponic system for celery}

Small perforations were made at the bottom of small plastic bags (36) that were used for the hydroponic system (Figure 1.B). A mixture of $9 \mathrm{~cm}$ of sand and $3 \mathrm{~cm}$ paddy straw was placed in each bag. $50 \mathrm{~g}$ of vermicompost was added to each bag in rows two (B), four (D) and five (E) from $T_{1}, T_{2}$ and $T_{3}$, respectively. The treatment details for the cultivation of celery using hydroponic system are as follows: (i) Treatment A: 3 inches of sand +1 inch paddy straw $+100 \mathrm{ml}$ of normal nutrients solution per day +1 celery plant. (ii) Treatment B: 3 inches of sand +1 inch paddy straw $+100 \mathrm{ml}$ of vermiwash made from $\mathrm{T}_{1}$ (Lime leaves) per day $+100 \mathrm{~g}$ of vermicompost from $\mathrm{T}_{1}+1$ celery plant. (iii) Treatment C: 3 inches of sand +1 inch paddy straw $+100 \mathrm{ml}$ of water per day +1 celery plant. (iv) Treatment D : 3 inches of sand +1 inch paddy straw +100 $\mathrm{ml}$ of vermiwash made from $\mathrm{T}_{2}$ (Neem leaves) per day + $100 \mathrm{~g}$ of vermicompost from $\mathrm{T}_{2}+1$ celery plant. (v) Treatment $\mathrm{E}: 3$ inches of sand +1 inch paddy straw +100 $\mathrm{ml}$ of vermiwash made from $\mathrm{T}_{3}$ (equal proportions of neem and lime leaves) per day) $+100 \mathrm{~g}$ of vermicompost from $\mathrm{T}_{3}$ +1 celery plant

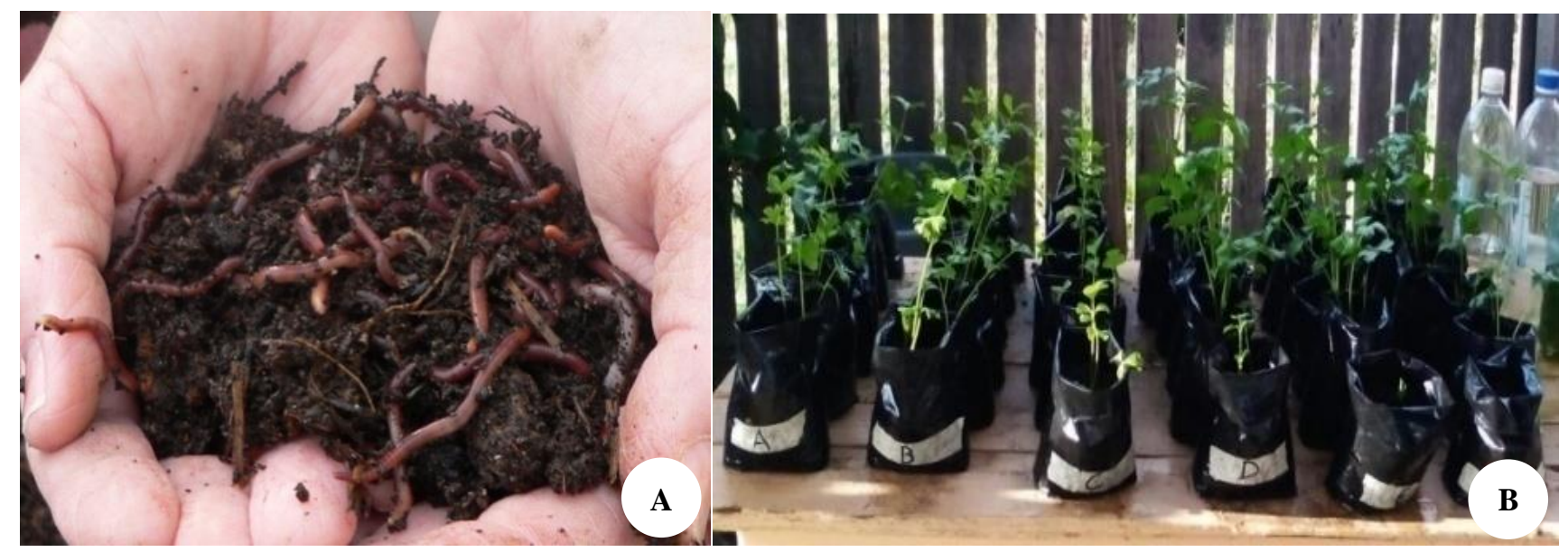

Figure 1. A. Earthworms used in the study; B. Arrangement of seedlings 
Microbial analysis (Aneja 1996)

Preparation of nutrient agar

About $14 \mathrm{~g}$ of nutrient agar powder was weighed and suspended in $500 \mathrm{ml}$ of distilled water in a $1000 \mathrm{ml}$ flask. The mixture was then boiled and swirled. After dissolving, the mixture was then placed in an autoclave at $121^{\circ} \mathrm{C}$ for sterilization for about 20 minutes then cooled to $47-50^{\circ} \mathrm{C}$. It was then poured into sterile Petri dishes allowed to gel.

\section{Culturing of microorganisms}

About $0.1 \mathrm{~g}$ of soil sample was weighed and dissolved in $10 \mathrm{ml}$ of water in a test tube. Each Petri plate was labeled according to the respective substrate that was streaked onto it. After streaking, the plates were sealed and incubated at $37^{\circ} \mathrm{C}$ for 24 hours. Total microbial count (included bacteria and fungi) was done after incubation along with morphological description of each colony present.

\section{Gram staining procedure for identifying the type of bacteria}

The chosen bacterial colony from the cultured plate was removed with an inoculating loop and thin smear of the isolated bacterial colony was made on the slide in a circular direction on a drop of distilled water. The smear was then fixed by swiftly heating through a Bunsen flame. After drying, the slide was then flooded with crystal violet for 30 seconds and then washed with distilled water. After washing off crystal violet from the side, the slide was then flooded with Gram iodine for 1 minute and then decolorized by tilting the slide and dropwise rinsing with $95 \%$ ethanol. Slide was then washed with distilled water for few seconds and stained with 5-6 drops of safranin for 20 seconds then rewashed. After counterstaining, the slide was blotted and air-dried. It was then examined under a microscope using oil immersion to identify bacterial colonies.

\section{Neem treatment and pest management}

About $600 \mathrm{~g}$ of neem leaves were collected and boiled with 11 of water. After boiling, the mixture was diluted with 51 of water and mixed with $50 \mathrm{ml}$ of soap. The neem extracts were then sprayed as pest management on plants three weeks after planting in treatments B, D and E.

\section{Plant growth parameters}

Plant growth parameters such as plant height and number of leaves recorded per week for period of 6 weeks. Percentage increase was calculated by using the following formula:

$\%$ increase in plant height /number of leaves $=($ week 6-week 1)/week 6 x 100

Agronomic data taken at harvesting included height, root biomasses, number of shoots, number of leaves, and diameter of stem.

\section{RESULTS AND DISCUSSION}

Vermicompost made from leaves of neem $\left(\mathrm{T}_{2}\right)$ and lime+neem $\left(\mathrm{T}_{3}\right)$ was slightly acidic $(\mathrm{pH} 5.89)$ while it was more neutral for vermicompost made from $\mathrm{T}_{1}(\mathrm{pH}$ 7.54). All $\mathrm{pH}$ levels except $\mathrm{T}_{2}$ were within the $\mathrm{pH}$ ranges 6.5-7.5 which is the $\mathrm{pH}$ that most plant nutrients are optimally available for plant growth. Nitrogen level was the lowest in $\mathrm{T}_{3}$ followed by $\mathrm{T}_{1}$ and was the highest in $\mathrm{T}_{2}$. Statistical analysis (ANOVA) showed that the difference in physicochemical parameters is not significant $(p=0.34)$. Nitrogen is required by plants in the largest quantity and is most frequently the limiting factor in growth, development and productivity. A plant receiving adequate nitrogen will exhibit enhanced growth (Perchlik and Tegeder 2017). Phosphorus was the lowest in $T_{3}$ followed by $T_{1}$ and the highest in $\mathrm{T}_{2}$. Potassium level was lowest in $\mathrm{T}_{1}$ followed by $\mathrm{T}_{3}$ and the highest in $\mathrm{T}_{2}$. Potassium is an essential plant nutrient and is required in large amounts for proper growth and reproduction of plants. Copper was the lowest in $T_{2}$ followed by $T_{3}$ and the highest in $T_{1}$. Copper activates the biosynthesis of enzymes and proteins critical for the metabolisms in plants (Yruela 2005). Zinc was the lowest in $\mathrm{T}_{2}$ followed by $\mathrm{T}_{1}$ and was the highest in $\mathrm{T}_{3}$ (Table 1 ).

Zinc is a plant micro-nutrient and is essential for the synthesis of enzymes essential for nitrogen metabolism, energy transfer and protein synthesis. Therefore, its deficiency will result in significant growth retardation and reduction in plant yield (Hafeez et al. 2013). Manganese was the lowest in $\mathrm{T}_{3}$ followed by $\mathrm{T}_{2}$ and the highest in $\mathrm{T}_{1}$. Manganese contributes significantly to plant physiological systems and structural formation of proteins designed for photosynthesis and other biochemical reactions (Millaleo et al. 2010). Iron was the lowest in $T_{2}$ followed by $T_{3}$ and the highest in $\mathrm{T}_{3}$. Iron is needed for chlorophyll synthesis and maintenance of chloroplast structure. Deficiency in iron leads to poor plant health, reduced productivity and quality of yield (Rout and Sahoo 2015). Magnesium was the lowest in $T_{3}$ and the highest in $T_{1}$. Magnesium is an essential macronutrient for plants. It has a range of key roles in many plant physiological functions (Guo et al. 2005). Calcium was the lowest in $T_{2}$ and the highest in $T_{1}$. Calcium is considered a secondary plant nutrient and is required for structural function in cell walls and membranes (Marschner 1995).

Microbial analyses of vermiwash and vermicompost were conducted during the third week to ascertain the presence of microbes. Total microbial count on vermiwash was the highest in $T_{1}$ and the lowest in $T_{3}$. The highest number of bacteria was seen in $T_{1}$ as well as the highest number of fungi as compared to the other samples. The highest microbial count in $\mathrm{T}_{1}$ is due to the substrate used to prepare the vermiwash which is lime leaves which may be attributed to weak presence of antimicrobial properties. Also, microbes were deposited from earthworm casting and some also came from the cattle dung used, however, earthworm casting and cattle dung was also used to prepare the other vermiwash units. The main reason for the highest amount of microbes in $T_{1}$ is the use of lime leaves compared to neem leaves and a combination of neem and 
lime leaves in the other two vermiwash units respectively because of the presence of several antimicrobial active ingredients in neem leaves. In vermicompost, similar results were obtained where the highest number of bacteria, as well as fungi, was found in vermicompost from $T_{1}$ (Figure 2). Statistical analysis (ANOVA) done for results obtained on vermiwash showed that the results were not statistically significant. Statistical analysis (ANOVA) showed that the $p$-value $0.17(p>0.05)$ and for treatments and $p$ of $0.44(p>0.05)$ for the different microbes. For statistical analysis conducted on vermicompost, it was seen that results were statistically significant for the different microbes and were not statistically significant for treatments where treatments have a p-value of 0.48 ( $p>$ $0.05)$ and the different microbes have a p-value of 0.01 ( $p<$ 0.05). Earthworm activities enhance the beneficial population and in some cases may have repressive responses to pathogens in the soil which allows for healthier plants (Yakushev 2011; Kiyasudeen et al. 2016).

Plant heights were measured on a weekly basis for 6 weeks and there was a significant difference between the plants' height recorded over the 6 weeks period (based on ANOVA). The highest mean growth and percentage increase $(80 \%)$ were seen in plants grown in D treated with $\mathrm{T} 2$ followed by plants grown in B treated with $\mathrm{T} 1$, while the lowest height was seen in plants grown in the control medium (C)which was treated with only water (Table 2). Analyses showed the highest level of nitrogen present in $\mathrm{T} 2$ followed by $\mathrm{T} 1$ and nitrogen is a significant player of chlorophyll and boosts plant growth and development (Perchlik and Tegeder 2017).
Number of leaves was counted on a weekly basis for 6 weeks and a significant difference was also in the number of leaves over the 6 weeks period. The highest number of leaves was found in plants grown in B treated with $\mathrm{T} 1$ followed by those grown in D treated with $\mathrm{T} 2$ and the lowest number of leaves was found in the control. Magnesium was highest in T1 followed by T2 (Table 3). Magnesium plays a pronounced role in many enzyme activities and structural stabilization of tissues and its deficiency can result in poor plant health (Guo et al. 2016). Magnesium deficiency is reflected in diminutive roots and shoots and leaves with necrotic spots resulting from the impairment of carbon metabolism and chlorophyll deficiency (Brady et al. 2005; Guo et al. 2005; Herman and Verbruggen 2005).

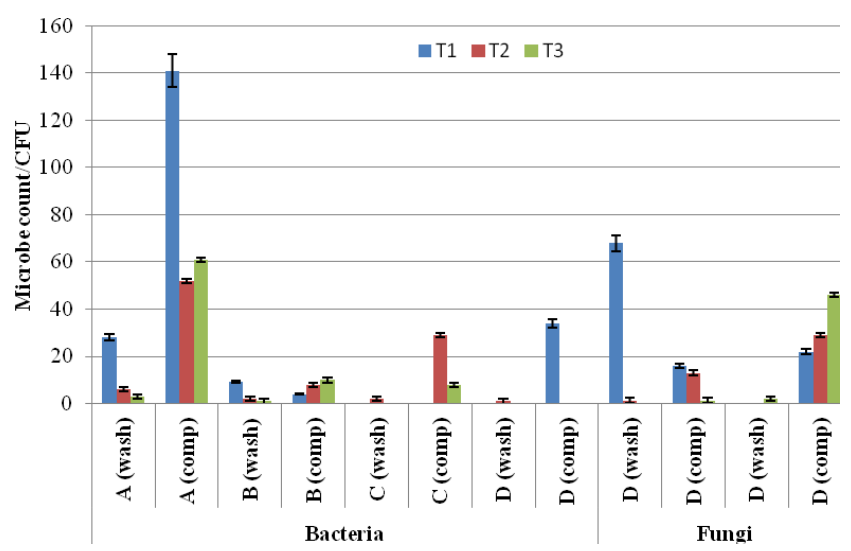

Figure 1. Microbial count of vermiwash and vermicompost (Mean \pm SD)

Table 1. Nutrient status of vermicompost produced from various plant materials

\begin{tabular}{lcrrrrrrrrrr}
\hline Treatment & & & \multicolumn{9}{c}{ Physico-chemical parameters (mg/kg) } \\
& $\mathbf{p H}$ & $\mathbf{N}$ & $\mathbf{P}$ & $\mathbf{K}$ & $\mathbf{C u}$ & $\mathbf{Z n}$ & $\mathbf{M n}$ & $\mathbf{F e}$ & $\mathbf{M g}$ & $\mathbf{C a}$ & $\mathbf{O C}$ \\
\hline $\mathrm{T}_{1}$ & 7.54 & 13625 & 123 & 28450 & 0.65 & 38.1 & 39.8 & 4.92 & 239 & 940 & 12.6 \\
$\mathrm{~T}_{2}$ & 5.89 & 14725 & 183 & 50700 & 0.15 & 31.0 & 23.2 & 1.49 & 210 & 478 & 29.2 \\
$\mathrm{~T}_{3}$ & 6.82 & 11175 & 99.8 & 35850 & 0.28 & 41.4 & 15.9 & 2.50 & 156 & 503 & 29.5 \\
\hline
\end{tabular}

Table 2. Plant height obtained from celery plants grown in six different treatments (Mean \pm SD)

\begin{tabular}{lccccccc}
\hline \multirow{2}{*}{ Treatment } & $\mathbf{1}$ & $\mathbf{2}$ & $\mathbf{3}$ & Week & $\mathbf{5}$ & $\mathbf{6}$ & \% increase \\
\hline $\mathrm{A}$ & $5.57 \pm 1.83$ & $10.18 \pm 3.99$ & $12.57 \pm 3.63$ & $16.08 \pm 5.5 .54$ & $16.85 \pm 8.68$ & $18.27 \pm 9.45$ & 69.51 \\
$\mathrm{~B}$ & $6.12 \pm 2.13$ & $10.18 \pm 2.94$ & $12.45 \pm 1.61$ & $17.92 \pm 2.52$ & $21.42 \pm 3.75$ & $24.03 \pm 3.81$ & 74.53 \\
$\mathrm{C}$ & $4.32 \pm 0.32$ & $8.97 \pm 1.03$ & $10.12 \pm 1.41$ & $12.28 \pm 1.86$ & $12.82 \pm 1.99$ & $13.52 \pm 2.55$ & 68.05 \\
$\mathrm{D}$ & $5.17 \pm 0.96$ & $11.58 \pm 3.52$ & $12.4 \pm 2.60$ & $18.78 \pm 4.30$ & $23.67 \pm 6.03$ & $26.1 \pm 6.35$ & 80.19 \\
$\mathrm{E}$ & $5.48 \pm 0.33$ & $10.63 \pm 5.54$ & $10.7 \pm 4.78$ & $15.55 \pm 7.51$ & $18.18 \pm 8.41$ & $20.12 \pm 8.71$ & 72.76 \\
\hline
\end{tabular}

Table 3. Average leaf number obtained from celery plants (Mean \pm SD).

\begin{tabular}{|c|c|c|c|c|c|c|c|}
\hline \multirow{2}{*}{ Treatment } & \multicolumn{6}{|c|}{ Week-number of leaves } & \multirow[t]{2}{*}{$\%$ increase } \\
\hline & 1 & 2 & 3 & 4 & 5 & 6 & \\
\hline $\mathrm{A}$ & $7 \pm 2.28$ & $7 \pm 2.28$ & $11.83 \pm 4.12$ & $13.5 \pm 6.77$ & $15.83 \pm 8.08$ & $16.33 \pm 8.26$ & 57.13 \\
\hline B & $8 \pm 1.26$ & $8 \pm 1.26$ & $13.33 \pm 4.59$ & $19.33 \pm 4.84$ & $22.33 \pm 4.55$ & $23.83 \pm 4.45$ & 66.43 \\
\hline $\mathrm{C}$ & $8.17 \pm 1.33$ & $8.17 \pm 1.33$ & $10.33 \pm 3.44$ & $11.5 \pm 2.26$ & $13.33 \pm 2.50$ & $17.33 \pm 4.32$ & 52.86 \\
\hline $\mathrm{D}$ & $7 \pm 3.10$ & $7 \pm 3.10$ & $11.83 \pm 6.11$ & $18.67 \pm 4.27$ & $21.83 \pm 4.53$ & $24.33 \pm 2.73$ & 71.23 \\
\hline $\mathrm{E}$ & $6.67 \pm 2.16$ & $6.67 \pm 2.16$ & $10.83 \pm 4.62$ & $15.5 \pm 6.68$ & $18.67 \pm 8.07$ & $20.33 \pm 8.78$ & 67.19 \\
\hline
\end{tabular}


Table 4. Agronomic features after harvest

\begin{tabular}{lccccc}
\hline Treatment & Height/cm & No. of shoots & No. of leaves & $\begin{array}{c}\text { Diameter of main } \\
\text { stem/cm }\end{array}$ & $\begin{array}{c}\text { Root weight } \\
\text { harvest/g }\end{array}$ \\
\hline A & $14.8 \pm 5.6$ & $3 \pm 1.2$ & $13 \pm 3.6$ & $0.3 \pm 0.01$ & $3.1 \pm 1.2$ \\
B & $17.2 \pm 8.2$ & $5 \pm 3.4$ & $24 \pm 5.7$ & $0.4 \pm 0.02$ & $19.2 \pm 5.4$ \\
C & $11.5 \pm 4.7$ & $4 \pm 2.8$ & $12 \pm 6.2$ & $0.2 \pm 0.01$ & $3.9 \pm 2.4$ \\
D & $18.5 \pm 6.7$ & $5 \pm 3.1$ & $17 \pm 9.1$ & $0.4 \pm 0.01$ & $28.8 \pm 8.7$ \\
E & $15.0 \pm 5.8$ & $4 \pm 2.1$ & $14 \pm 5.6$ & $0.4 \pm 0.00$ & $20.1 \pm 6.5$ \\
\hline
\end{tabular}

Overall plants parameters showed that plants that were grown in treatments $\mathrm{D}$ and $\mathrm{B}$ showed more pronounced growth followed by those in $\mathrm{E}$ then $\mathrm{F}$ and $\mathrm{A}$ and control $\mathrm{C}$. Highest plant height was seen in those that were grown in $\mathrm{D}$ due to the high amount of nitrogen present in the vermicompost. Number of leaves was significantly high in $\mathrm{B}$ as compared to the others. Width of the main stem was equal in $\mathrm{B}, \mathrm{D}$ and $\mathrm{E}$, while root weight after harvest was significantly higher in D as compared to the others (Table 4). Statistical analysis (ANOVA) done on the overall parameters indicated a statistical significance for the different parameters with $p$-value of $2 \mathrm{E}-05$ whereas it was statistically not significant for treatments with a $p$-value of 0.047 ( $p>0.05)$.

In conclusion, vermiwash and vermicompost when used as a composite can supplant nutrient solution in hydroponic systems since it promotes greater plant growth in its entirety. Vermiwash and vermicompost made from lime leaves have proven to be a better substitute for plant growth resulting in taller plants with greater width. They constitute adequate amount of macro and micronutrients for plants and release these nutrients slowly so that they are readily accessible and remain in the soil much longer. Also, these nutrients are in right balance, hence they don't react to affect the quantity available or absorption of others and thus maintaining a healthy soil ecosystem.

\section{REFERENCES}

Aneja KR.1996. 2nd Experiment in Microbiology, Plant Pathology Tissue culture and Mushroom Cultivation. Vishwas Prakashan, New Delhi.

Ansari A, Ismail S. 2012. Role of earthworms in Vermitechnology. J Agric Technol 8: 403-415

Balamurugan S. 2014. In vitro antifungal activity of Citrus aurantifolia Linn plant extracts against phytopathogenic fungi Macrophomina phaseolina. Intl Lett Nat Sci 13: 70-74. DOI 10.18052/www.scipress.com/ILNS.13.70

Brady KU, Kruckeberg AR, Bradshaw Jr. HD. 2005. Evolutionary ecology of plant adaptation to serpentine soils. Annu Rev Ecol Evo Syst 36: 243-266. DOI: 10.1146/annurev.ecolsys.35.021103.105730

Buchanan DN, Omaye ST. 2013. Comparative study of ascorbic acid and tocopherol concentrations in hydroponic-and soil-grown lettuces. Food Nutr Sci 4 (10): 1047-1053. DOI: 10.4236/fns.2013.410136

Daniels S. 2006. Citrus peel extract shows benefits for diabetes. Life Sci 79: $365-73$.

Deinlein U, Stephan AB, Horie T, Luo W, Xu G, Schroedel JI. 2014. Plant salt-tolerance mechanisms. Trends Plant Sci 19 (6): 371-379. DOI: $10.1016 /$ j.tplants.2014.02.001

Domínguez J. 2004. State of the Art and New Perspectives on Vermicomposting Research. In: Edwards CA. (ed.). Earthworm
Ecology. CRC Press, Boca Raton, FL. DOI: 10.1201/9781420039719.ch20

Fathima M, Sekar M. 2014. Studies on growth promoting effects of vermiwash on the germination of vegetable crops. Intl $\mathrm{J}$ Curr Microbiol App Sci 3 (6): 564-570.

Flowers TJ, Muscolo A. 2015. Introduction to the special issue: Halophytes in a changing world. AoB Plants 7: 231-245. DOI: 10.1093/aobpla/plv020

Gajalakshmi S, Abbasi SA. 2004. Neem leaves as a source of fertilizercum-pesticide vermicompost. Bioresour Technol 92: 291-296. DOI: 10.1016/j.biortech.2003.09.012

Gauri M, Javed A, Shahid KM. 2015. A review of Apium graveolens (Karafs) with special reference to Unani medicine. Intl Arch Integr Med 2: 131-136.

Gruda N. 2009. Do soilless culture systems have an influence on product quality of vegetables? J Appl Bot Food Qual 82: 141-147. DOI: $10.18452 / 9433$

Guo W, Nazim H, Liang Z, Yang D. 2015. Magnesium deficiency in plants: An urgent problem. Crop J 4: (2): 83-91. DOI: 10.1016/j.cj.2015.11.003

Hafeez B, Khanif YM, Saleem M. 2013. Role of zinc in plant nutrition-A review. Amer J Exp Agric 3 (2): 374-391. DOI: 10.9734/AJEA/2013/2746

Hao F, Kumar S, Yadav N, Chandra D. 2014. Neem components as potential agents for cancer prevention and treatment. Biochimica et Biophys Acta 1846 (1): 247-257. DOI: 10.1016/j.bbcan.2014.07.002

Hermans C. Verbruggen N. 2005. Physiological characterization of Mg deficiency in Arabidopsis thaliana. J Exp Bot 56: 2153-2161. DOI: 10.1093/jxb/eri215

Homer F. 2003. Soil Analyses Manual. Central Analytic and Environment Monitoring Services, Agriculture Research Department. LBI, Guyana. Ismail SA. 2005. The Earthworm Book. Other India Press, Mapusa, Gao.

Jaikishun S. Hunte N, Ansari AA. Gomathinayagam S. 2014. Effect of vermiwash from different sources (Bagasse, neem, paddy straw, in different combinations) in controlling fungal diseases and growth of tomato (Lycopersicon esculentum) fruits in Guyana. J Biol Sci 14 (8): 501-507. DOI: 10.3923/jbs.2014.501.507

Kiyasudeen KS, Ibrahim MH, Quail S, Ismail SA. 2016. Vermicompost, its applications and derivatives. In: Prospects of Organic Waste Management and the Significance of Earthworms. Applied Environmental Science and Engineering for a Sustainable Future. Springer, Cham. DOI: 10.1007/978-3-319-24708-3

Kooti W. Daraei N. 2017. A review of the antioxidant activity of celery (Apium graveolens L). J Evid-Based Compl Altern Med 22 (4): 10291034. DOI: $10.1177 / 2156587217717415$

Koyama M, Nakamura C, Kozo N. 2013. Changes in phenols contents from buckwheat sprouts during growth stage. J Food Sci Technol 50 (1): 86-91. DOI: $10.1007 / \mathrm{s} 13197-011-0316-1$

Marschner H. 1995. Mineral Nutrition of Higher Plants. 2nd ed. Academic Press, London.

Millaleo R, Reyes-Díaz M, Ivanov AG, Mora ML, Alberdi M. 2010. Manganese as essential and toxic element for plants: transport, accumulation and resistance mechanisms. J Soil Sci Plant Nutr 10 (4): 476-494. DOI: 10.4067/S0718-95162010000200008

Nwankwo IU, Osaro-Matthew RC, Ekpe IN. 2015. Synergistic antibacterial potentials of Citrus aurantifolia (Lime) and honey against some bacteria isolated from sputum of patients attending Federal Medical Center, Umuahia. Intl J Curr Microbiol Appl Sci 4: 534-44. 
Paul R, Prasad M, Sah NK. 2011. Anticancer biology of Azadirachtaindica L (neem): a mini-review. Free Radic Res 12: 467 476. DOI: $10.4161 /$ cbt.12.6.16850

Perchlik M, Tegeder M. 2017. Improving plant nitrogen use efficiency through alteration of amino acid transport processes. Plant Physio 175 (1): 235-247. DOI: 10.1104/pp. 17.00608

Prakash P, Prasad U, Sunkar W, Sai Krishna NMD, Gala AA, Kumar A 2016. Formulation of vermiwash and humic acid and its application on Allium cepa. Biosci Biotechnol Res Asia 13 (1): 523-5. DOI: $10.13005 / \mathrm{bbra} / 2064$

Resh HM, Howard M. 2012. Hydroponic Food Production: A Definitive Guidebook for the Advanced Home Gardener and the Commercial Hydroponic Grower. 6th ed. CRC Press, Boca Raton, FL.
Rout GR, Sahoo S. 2015. Role of iron in plant growth and metabolism. Rev Agric Sci 3: 1-24. DOI: 10.7831/ras.3.1

Treftz C, Omaye ST. 2015. Comparisons between hydroponic and soil systems for growing strawberries in a greenhouse. Intl J Agr Ext 3 (3): 195-200.

United Nations, Department of Economic and Social Affairs, Population Division. 2015. World Population Prospects: The 2015 Revision, Key Findings and Advance Tables. Working Paper No. ESA/P/WP.241

Yakushev AV, Bubnov IA, Semenov AM. 2011. Estimation of the effects of earthworms and initial substrates on the bacterial community in vermicomposts. Eurasian Soil Sci 44: 1117-1124. DOI: 10.1134/S1064229311100164

Yruela I. 2005. Copper in plants. Braz J Plan Physiol. 17: 145-156. DOI: 10.1590/S1677-04202005000100012 